NBER WORKING PAPER SERIES

\title{
FINANCIAL SECTOR PROFITABILITY AND \\ DOUBLE-GEARING
}

\author{
Mitsuhiro Fukao
}

Working Paper 9368

http://www.nber.org/papers/w9368

\section{NATIONAL BUREAU OF ECONOMIC RESEARCH 1050 Massachusetts Avenue \\ Cambridge, MA 02138}

December 2002

This paper is forthcoming in "Structural Impediments to Growth in Japan", edited by Magnus Blomstrom, Jennifer Corbett, Fumio Hayashi and Anil Kashyap, for the University of Chicago Press. The author would like to thank Anil Kashyap, Larry Meissner and other participants of the "Structural Impediments to Growth in Japan" conference for valuable comments on an earlier draft. The views expressed herein are those of the authors and not necessarily those of the National Bureau of Economic Research.

(C) 2002 by Mitsuhiro Fukao. All rights reserved. Short sections of text, not to exceed two paragraphs, may be quoted without explicit permission provided that full credit, including $(\mathcal{C}$ notice, is given to the source. 
Financial Sector Profitability and Double-Gearing

Mitsuhiro Fukao

NBER Working Paper No. 9368

December 2002

JEL No. G28, G21, G22, O16

\section{$\underline{\text { ABSTRACT }}$}

In this paper, I show that Japan will not be able to have a viable banking sector without stopping deflation. The banking industry has not shown a profit since fiscal 1993 (ended March 1994) if one excludes capital gains from stock and real estate portfolios. I quantify the financial condition of the sector and show that interest margins have been too low to cover the increase in loan losses brought about by the weak economy.

Banks cannot raise margins for several reasons: competition with subsidized government sponsored financial institutions (GFIs); intense political pressure, backed by the Financial Services Agency (FSA), to make new loans to small and medium companies; and deflation-weakened borrowers. I expect that the Japanese government will have to nationalize most of the banking sector by 2005. Capital injections will not solve the problems.

Established Japanese life insurance companies are also troubled because they over-promised the amount that they could pay. This can be corrected through a reorganization where the promised interest rates are cut. But this is complicated because Japanese banks and life insurance companies are providing each other capital - a practice called double-gearing. Weakened banks ask insurance companies to provide equity capital and subordinated loans. In return, the mutual life insurers ask banks to subscribe their surplus notes (similar to non-voting redeemable preferred shares) and subordinated debt. The risks of double-gearing are analyzed.

Mitsuhiro Fukao

Faculty of Business and Commerce, Keio University

2-15-45 Mita, Minato-ku, Tokyo 108-8345, Japan

fukao@fbc.keio.ac.jp 
The Japanese economy's average annual real growth rate was only 0.8\% from 1991 to 2001 . Reflecting the weak economy, Japan has not been able to restore stability in its financial sector even though more than a decade has passed since the 1980s bubble. The Bank of Japan (BOJ) has had a zero nominal interest rate policy most of the time since February 1999, but it has been ineffective because of deflation. By the end of 2001, the GDP deflator was about 7\% below its 1994 peak when adjusted for the 1997 consumption tax hike. The index was falling at annual rate of $1.5 \%$ at the end of 2001 . Given the estimated $6 \%$ deflationary GDP gap and expected negative real growth in 2002, deflation is likely to accelerate to more than $2.0 \%$ by early 2003. (See JCER 2002, ch 1 ).

In this chapter, I show that Japan will not be able to have a viable banking sector without stopping deflation. The banking industry has not shown a profit since fiscal 1993 (ended March 1994) if one excludes capital gains from stock and real estate portfolios. Interest margins have been too low to cover the increase in loan losses brought about by the weak economy.

Banks cannot raise margins for several reasons: competition with subsidized government sponsored financial institutions (GFIs); intense political pressure, backed by the Financial Services Agency (FSA), to make new loans to small and medium companie s; and deflation-weakened borrowers. I expect that the Japanese government will have to nationalize most of the banking sector by 2005. Capital injections will not solve the problems.

Established Japanese life insurance companies also face a serious situation. In the 1980s and early 1990s they promised high minimum yields on long-term contracts. For whatever reason, the companies did not match these long-term liabilities with long-term fixed-income investments. Under the BOJ zero-interest rate policy, insurers thus are suffering large negative carry. (Carry is the industry term for the difference between a product's income and its associated costs).

A complicating factor in this dire picture is banks and life insurance companies providing each other capital - a practice called double-gearing. Weakened banks ask insurance companies to provide equity capital and subordinated loans. In return, the mutual life insurers ask banks to subscribe their surplus notes (similar to non-voting redeemable preferred shares) and subordinated debt. When Chiyoda Life failed in October 2000, Tokai Bank lost $¥ 74$ billion. The Financial Services Agency (FSA) actively encourages this dangerous practice. Thus, Shokichi Takagi, Director of FSA's Supervision Department, has 
publicly stated that double-gearing among financial institutions is highly beneficial to enhance public confidence (Nihon Keizai Shinbun, 27 Nov 2001).

The life insurers' problem is easier to solve than the banks' problem. Using a reorganization procedure, life insurance companies can fail, and cut promised interest rates on their policies. On the other hand, banks runs would ensue if the government did not fully pay the depositors of a failed large bank because a large part of the banking sector is either insolvent or very nearly so. In such a situation, the government would have to bear the full brunt of defaulting loans at a time when its own debt to GDP ratio is rising by 10 percentage points a year. If things continue as they are, the Japanese government is unlikely to maintain investment-grade credit ratings on its bonds.

The chapter continues with an analysis of banks' bad loans and their under-reserving for them. The deteriorating condition of banks is then considered, and the causes of bank unprofitability examined. As part of this, the effects of deregulation and the role of government-sponsored financial institutions is considered. Turning to life insurance companies, their problems and weak supervision are discussed. The risks of the banks and insurers engaging in double-gearing is then analyzed.

\section{$1 \quad$ Banks' Bad Loans}

Table 1 and Table 2 show data on problem loans of Japanese banks. Japanese banks have acknowledged $¥ 82$ trillion in losses from bad loans for the ten years through March 2002 . In spite of this enormous loss, they still have more than $¥ 42$ trillion of disclosed bad loans, about $8 \%$ of their loan portfolios.

I am one of the many who feel the disclosed figures understate the real situation. The FSA collects data on "classified loans", a broader concept of problem loans, but does not discloses it for individual banks. Under the FSA's Bank Examination Manual, banks are required to rate their loans, taking account of default risk and quality of collateral. There are four grades: normal, substandard, doubtful, and estimated-loss loans. The last three are considered "classified" loans. Banks then estimate their loan-loss reserves and the amount of write-offs. Because of the broader definition, the amount of classified loans is almost twice that of disclosed bad loans. Total classified loans for all banks was ¥71.1 trillion in March 2002. 


\subsection{Under-Reserving}

Total loan loss reserves of Japanese banks have been low relative to those of US banks. While US bad loans declined from 3\% of total loans in 1992 to $1 \%$ in 1999, the Japanese ratio rose from $2 \%$ to $6 \%$ (Figure 1). Loan-loss reserves in the United States have been above $160 \%$ of bad loans since 1994, while in Japan they have been in the $40 \%$ to $60 \%$ range (Figure 2). We can clearly see that although the US banking sector recovered quickly from its bad-loan problems in early 1990s, the Japanese situation has been deteriorating even with the 1999 capital injection by the government.

Many analysts of Japanese banks suspect that the banks are not recording enough loan-loss reserves. This problem is exacerbated by the lenient reserving policy stipulated by the FSA Bank Examination Manual. Japanese banks usually calculate loan-loss reserves by dividing their loans into the FSA-mandated categories, then estimated losses for each group using the following time horizons.

1 Normal loans and sub-standard loans without arrears or reduced interest rates: expected one-year loss rate;

2 Sub-standard loans with arrears or reduced interest rates and doubtful loans: expected three-year loan loss rate;

Most loans are routinely rolled over, so the one-year figures understate the net present value of future losses over the true life of the loans in category (1). Thus, instead of a one-year rate, banks should reserve using, as a minimum, the three-year cumulative rate for all sub-standard loans.

To estimate more appropriate reserve figures, I have estimated required loan loss reserves based on FSA data of classified loans. A Bank of Japan (1997) sample study looked at the actual subsequent loan losses of 18 banks for each category of classified loans on their fiscal 1993 reports (Table 3). At the end of three years (in March 1997) about 17\% of substandard loans and over $75 \%$ of doubtful loans had been lost and almost $100 \%$ of estimated loss loans.

These figures indicate that banks should keep larger loan loss reserves. I have calculated estimated reserves requirements based on $20 \%$ of substandard loans, $70 \%$ of 
doubtful loans, and $1 \%$ of normal loans. This last is because of the migration of normal loans to classified loans. The results are in Table 2 row $\mathrm{C}$.

By comparing rows $\mathrm{C}$ and $\mathrm{D}$, we can estimate the lower bound of under-reserving (row C minus row D). Although substantially below the estimated 1997 level, under-reserving remains large.

Figure 3 provides further evidence of the deteriorating condition of banks. Although the bad-loan to totalloan ratio has stabilized for city banks, for first- and second-tier regional banks it has been increasing rapidly. The large 1995 increase for regional banks in part reflects changes in disclosure requirements, but the trend since is due primarily to deteriorating loan quality.

Corresponding to the flow - profit - figures, the capital position of Japanese banks has been deteriorating. Under Japanese accounting rules for banks and lenient application by the regulators, BIS capital ratios have been manipulated in many ways.

First, banks have under-reserved against bad loans, as explained above. This tends to increase bank core capital by the same amount.

Second, banks have large deferred-tax assets on their balance sheets even though they have been losing money continually since 1993 and loss carry-forwards are limited to five years. There is little prospect of utilizing the deferred-tax asset by showing genuine profit in the near future, so it should be written off.

Third, most of banks' subordinated loans are held by friendly life insurance companies. The banks, in turn, hold subordinated loans and surplus notes of the life companies. This is double-gearing and the cross-held quasi-capital should not be treated as genuine capital for either the banks or the life insurance companies.

Table 4 shows core (tier-1) capital adjusted for unrealized capital gains, under reserving, and deferred taxes for major Japanese banks since March 1998. On this calculation, eight banks had negative equity in 1998, but only two were nationalized. The capital ratio recovered in fiscal 1998, part due to the $¥ 6.2$ trillion in capital injected by the government, and rose further as stock prices recovered. But it began deteriorating again in 2000, the result 
of more loans going bad and stock prices falling. In September 2001 was at $0.86 \%$, below where it had been 3 years earlier.

The capital position of banks is quite sensitive to stock prices. Table 5 shows the capital structure of all commercial banks. Core capital based on traditional historical cost accounting is adjusted for unrealized capital gains on stocks, deferred taxes, the public capital injection, and under-reserving for loan losses. Although banks show $¥ 29.3$ trillion of capital on their balance sheet at the end of March 2002, this figure is inflated with $¥ 10.7$ trillion of deferred-tax credits (present value of the future tax shelter), ¥6.9 trillion of under-reserving, and $¥ 7.2$ trillion of government capital. Removing these amounts, the privately held equity of the banking sector is only $¥ 4.5$ trillion yen. This is very small compared to their $¥ 71.8$ trillion of problem loans.

Because the $¥ 34.4$ trillion market value of stocks held by banks is about 7.5 times their net capital, a $10 \%$ fall in the stock price index wipes out about $76 \%$ of their net capital. In the late 1980s and early 1990s, unrealized capital gains (the difference between column A and B) was very large and banks could withstand fluctuations in stock prices. However, in the 1990s, banks sold stock to realize gains to offset huge loan losses. The increase in book value of shares (column B) during the 1990s shows the banks were buying back most of the stock they sold.

\subsection{An Unprofitable Business}

Banking in Japan has become an unprofitable, structurally depressed industry. Excluding capital gains realized by selling shares and real estate, Japan's banks as a group have been in the red since the year ended March 1994 (fiscal 1993). The primary cause of this is low interest rates, which are squeezing profits.

Let us look at the profit structure of banks nation-wide. Table 6 shows the profit-loss accounts of all commercial banks. In the nine years from fiscal 1992 to fiscal 2000 , banks made around $¥ 10$ trillion each year as lending margin (row A, defined as interest and dividends earned minus interest paid). Revenue from such sources as bond and currency dealing and service charges were over $¥ 2$ trillion, and $¥ 3$ trillion more recently (row B). This includes all other revenue except capital gains realized on stocks and real estate. Revenues from banks' principal operations therefore amount to roughly $¥ 12$ trillion to $¥ 13$ trillion yen a year (row A + row B). 
Total costs - including personnel and other operating expenses - were over ?7 trillion (row C). Operating costs declined during 1998-2000 because of cost cutting measures. It is likely to be difficult to continue that pace of cost cutting. Certainly, the banks may cut labor costs further by reducing employment and cutting average compensation. But the banks have to invest heavily in information technology to remain competitive.

In the 1990s bank stinted on improving systems because of preoccupation with bad-loan problems, and now they have poor quality computer systems. Thus, for example, the zengin electronic fund transfer system, which is the main payment system among bank customers, cannot handle 2-byte codes, so it cannot send customer names and messages in kanji (characters).) As a result, more and more payments (especially utility bills) are handled by convenience store chains, which have installed sophisticated terminals.

Since the early 1990s more and more loans held by banks have turned into non-performing assets. Banks have suffered over $¥ 6$ trillion in loan losses each year since fiscal 1994, and $¥ 9$ trillion in the last year (row E). As a result, banks have not reported positive net operating profit since fiscal 1993 (row F). However, because of occasional realization of capital gains on stocks and real estate (row G), banks have shown a positive bottom line (row $\mathrm{F}+$ row $\mathrm{G}$ ).

The profit margin of Japanese banks is too small to cover the increase in default risk since the bubble burst. Two principal elements of this - the deregulation that has been going on since the 1980s and competition from government-sponsored financial institutions - are taken up in the following sections.

The nature of government regulation is a third factor. Thus, under the terms and condition of the government capital injection in March 1999, banks are legally required to maintain and increase loans to small and medium firms. Shinsei Bank, which reduced loans to such firms, was ordered by the FSA to increase its lending. Under these conditions, banks often disregard their procedures to make new loans to small companies, at ultimate cost to the banks and the economy as a whole because of the misallocation of resources. 


\subsection{Effects of Deregulation}

The average lending rate of Japanese banks was $1.8 \%$ in fiscal 2000 , while the average funding cost was $0.3 \%$ and the average intermediation cost was $1.2 \%$. Thus, the gross spread was only $0.35 \%$ (Japanese Bankers Association 2001). The average credit rating of borrowers from banks is about $\mathrm{BB}$, the annual loan loss rate is well over $1 \%$, which means a negative margin of $0.65 \%$. Part of this is offset by fees from borrowers and other customers, but a key fact is that the banks are making losses from lending.

One of the reasons for the small gross spread is the overhang of deposit interest rate controls until the early 1990s. When the government controlled deposit rates, banks easily made money taking deposits. This is seen in Figure 4.

Figure 4 decomposes the lending margin (interest earned minus interest paid) into regulatory rent and the true profit margin (the spread between the average lending rate and the market rate). The regulatory rent is taken as the difference between the banks' funding cost and the risk-free short-term money market rate. Notice that the true lending margin in much of the 1980s was negative, which suggests banks passed part of the rent on to borrowers

As deposit-rate controls were phased out in the late 1980s and early 1990s, banks tried to keep up profit margins by increasing lending rates relative to short-term market rates.

Although the banks have not raised their profit margin, borrowers are paying a higher interest rate in relation to the money market rate. Figure 5 shows movements of the average new lending rate, overnight call rate, and the implied ex post real interest rates computed by subtracted the GDP deflator inflation rate. Reflecting the BOJ's loose monetary policy, the real call rate fell from 1991 until 1998. On the other hand, the real rate of new lending has not fallen much because of the increasing gap between the new lending rate and the call rate.

Although the opportunity cost of borrowing for large creditworthy companies is close to the call rate, the cost for small and medium companies is close to the new lending rate. The refore, smaller companies have been less able than larger ones to enjoy the expansionary effect of loose money. This may have contributed to the relatively weak recovery of the small-business sector in the 1990s.

It was natural for banks to raise lending rates relative to market rates after removal of deposit rate controls. However, banks have not succeeded in obtaining enough of a margin to cover loan losses in a weak economy. At the same time, smaller borrowers have suffered from higher borrowing costs relative to large companies that have access to capital markets. 


\subsection{Government Financial Institutions}

In Japanese financial markets, the presence of government financial institutions (GFIs) is extremely large. Table 7 shows the market share of private banks and GFIs at the end of 2000 .

In the loan market, the GFI share reaches $30 \%$ to $40 \%$ in rural prefectures, although it is only $26 \%$ overall. GFIs make very long term loans at about $2 \%$. They are especially dominant in housing loans, holding more than haf the outstanding balance.

Table 8 shows the base lending rates of GFIs on 9 February 2001. Their rates on new lending are similar to those for short-term loans from private banks, but the average term is much longer.

GFIs obtain subsidies of about ¥1 trillion per year as direct subsidy and indirect subsidy of zero-cost capital. These are estimated to provide a 60 basis point cost advantage relative to private financial institutions. Further, they usually accept prepayment without penalties, so their loans are more attractive to borrowers. As a result, the rates banks can charge are significantly constrained. (See Higo (2001) on the role of GFIs and their institutional details.)

In the deposit market, the Postal Saving System (PSS) is a dominant player. Deposits are fully guaranteed by the government. Rates are set competitively against private deposit-taking institutions. There are more than 24,000 post offices, giving the system a branch network larger than all the city and regional banks combined. The largest private banking group, Mizuho, has only about 600 offices. The PSS does not charge account-maintenance fees, so it is difficult for private banks to charge such fees without alienating a large number of customers.

My calculations indicate banks have to raise their lending margin by 80 to 100 basis points to break even in the current economic environment of deflation and recession.

The loan losses in Table 6 for 1999 and 2000 understate true losses by some $¥ 1.5$ trillion each year due to under-reserving for bad loans. Therefore, banks lost about ¥3 trillion in each of those years before capital gains. Macroeconomic conditions deteriorated in 2001, so banks reported more than 9 trillion yen of loan losses in FY 2001 alone, partly recognizing the past understated losses.

By raising lending rates 100 basis points, banks can obtain an additional ¥5 trillion from their $¥ 500$ trillion loan portfolio, which would allow them to write-off bad loans as they surface. However, they can neither raise lending rates nor charge higher fees on depositors due to the institutional environment. If the rate of deflation 
accelerates, banks will run out of capital sooner or later and the government will be forced to take control of the sector.

$4 \quad$ Life Insurance Companies

Private life insurers are the second largest part of the financial services industry after commercial banks, with December 2000 total assets of $¥ 180$ trillion, which is about $35 \%$ of GDP. Limited competition and the robust economy allowed life insurance companies to enjoy fairly high growth and reasonably good profits until the early 1990s. Before the current crisis, there were 20 established companies, almost all organized as mutual companies.

Although the companies are less affected by the bad loan problem than banks, they face a serious problem. In the late 1980s and early 1990s they effectively sold massive amounts of what are forward-rate agreement options. The most important insurance products sold by Japanese companies in the 1980s and early 90s were whole- life insurance with term rider and long-term annuities. Moreover, most of them are sold as monthly payment plan. These promised high minimum guaranteed returns (yotei riritsu) over the life of a policy. As a result, life insurance companies effectively guaranteed high returns on future cash flow. Thus, until 1992, major Japanese life-insurance companies assumed a return on their assets of $5.5 \%$ or more in designing policies. In 1992 someone buying even a life annuity or whole-life insurance was guaranteed $5.5 \%$ by all the companies.

The profitability of an annuity to its issuer depends on the difference between assumed and actual results of three factors: return on invested assets, costs, and death rates. For cautious actuaries, assumed death rates and operating costs tend to be higher than actual rates. This provides some cushion for any short-fall in expected investment returns. However, for many insurers, the shortfalls in asset returns were too big to be covered.

Most companies did not match the terms of their assets and liabilities. Generally, the term on the asset side has been about 5 years, while the average on the liability side has been 15 to 20 years. When interest rates fell sharply in the 1990s, firms faced massive negative carry. Some companies were operating with little or no equity by the late 1990s. When they finally filed bankruptcy, most were deeply insolvent.

Beginning with the collapse of Nissan Life in April 1997, seven insurers had failed by mid 2002. Together they left $¥ 2.68$ trillion in negative equity. This loss has to be born by policyholders and the Policyholder Protection Fund (PPF) that depends on 
the contribution by healthie $\mathrm{r}$ companies. Table 9 shows the financial conditions of the failed companies. Although the companies reported fairly high solvency margins just before their failures, all were found to be insolvent after their bankruptcy. Table 10 shows solvency margins. Note that no company has failed since March 2001.

When a life insurance company fails, the court-appointed administrator cuts the liability of the company so as to make the company viable again. Most of the liability of an insurance company is policy reserve that corresponds to the accumulated saving of policyholders. Generally speaking, the surrender value of a policy corresponds to this value. Under the Japanese policyholder protection scheme, the PPF guarantees only $90 \%$ of the policy reserve and it does not protect guaranteed minimum returns. The PPF can also introduce a cancellation penalty on the policy reserve to reduce the cost of resolution.

As a result, policyholders at bankrupt insurers are hit on three sides. On average, they have lost about $10 \%$ of their accrued past saving. Guaranteed returns in most cases were cut down to $1 \%$ to $2 \%$. In addition, heavy early-withdrawal charges are levied on cancellations of policies of all types. In the case of Chiyoda Life, a policyholder faces a $20 \%$ charge for immediate cancellation. This charge declines gradually to two percent in the tenth year. One must wait 10 years to cancel without an early cancellation penalty. Because policyholders can realize the surrender value of policies quite easily before a firm fails, companies thought to be weak have faced heavy cancellations.

It is usually better for a healthy person to quickly cancel a cash-value life insurance policy with a failing company and get a new policy elsewhere than to stick to the existing policy. However, getting a new life policy is more expensive, and perhaps not possible, for an unhealthy person. This means the burden of an insurer's failure falls more heavily on those who have become less insurable.

\subsection{Weak Supervision}

The life insurance industry's crisis has been exacerbated by the forbearance policy of its supervisory authorities, the former Ministry of Finance and the FSA. Because of extremely lenient capital requirements and reluctance to close down unhealthy firms, most failed life insurance companies had large negative equity by the time of their formal failure.

The regulatory measure of capital requirements in insurance is the solvency margin, which relates net assets to estimated risk. The net assets are capital + risk reserves + general loan loss reserves + excess reserves over surrender value of polices + 
future profits + tax effect + subordinated debt. The estimated risk equals [(insurance risk $\left.)^{2}+(\text { interest rate risk }+ \text { asset value risk })^{2}\right]^{1 / 2}+$ management risk. The net assets are divided by the estimated risk and multiplied by 200 to obtain the solvency margin. The minimum ratio for sound companies is 200 . Below that, regulators are required to take corrective action.

The requirement was imported from the United States, but Japanese regulators have made a number of modifications that weaken the rule considerably, including setting the trigger levels for prompt corrective action much lower. Table 11 illustrates the major differences.

For a number of reasons the numerator in Japan is overstated. Especially worrisome is inclusion of a large deferred tax asset and future profits. Moreover, Japan generously includes assets with no liquidation value, although the US standard excludes them. Regarding the denominator side, Japanese risk weights are considerably lower than those of the United States. Thus, for publicly traded corporate equity (stock), the risk weight is about one-third the US level. For real estate and foreign currency assets, the risk weights are one-half the US levels.

The Financial Studies Group of the Japan Center for Economic Research, which I head, have tried to adjust for the differences in the solvency margin requirements in Japan and the United States. The quality of disclosure by life insurance companies has improved considerably since the mid 1990s, so we can do this from publicly available data. Figure 6 shows the results for the end of March 2000.

Based on what they disclose, all the major companies are above the $200 \%$ level, implying that they are all healthy. We have made three types of adjustments. The first uses US risk weights and adjusts for unrealized capital gains and losses, but allows inclusion of assets with no liquidation value. With these adjustments, two companies are deemed insolvent.

The second is closer to - but still somewhat less stringent than - the US standard. Specifically, we removed assets with no liquidation value. Three companies are insolvent under this definition.

The third approach involves removing subordinated debt from the capital base because its quality as capital is less than that of retained earnings and surplus notes (which are similar to the non voting redeemable preferred shares of joint stock companies). Under this measure, four companies were insolvent even when the Nikkei 225 was at 20,337, significantly higher than it is two years later as this is written.

Three companies that had negative adjusted solvency margins failed within a year: Chiyoda Life and Kyoei Life filed bankruptcy in October 2000, as did Tokyo Life 
in March 2001. The fourth company, Nichidan Life, received a capital injection from Axa, a French insurance company.

Figure 7 shows the same picture for March 2002. The disclosed ratios are more than 500\% except for one company. However, "Adjusted 2" indicates that the FSA should intervene in at least three weaker companies: Mitsui, Asahi, and Sumitomo Life. The Nikkei was 11,025 at that time. We estimated that a $20 \%$ fall in the index would pull the solvency margin of weaker companies down by about 100 points. Therefore, a Nikkei below 10,000 means three companies probably are critically under-capitalized and three others would require prompt corrective actions under US standards.

$5 \quad$ Increasing Double-Gearing

All the major life insurance companies are mutual companies, so there is no formal cross-holding of shares. However, the insurers are major shareholders of the banks collectively owning $10 \%$ or more of each city bank during the 1990s. Moreover, banks and life insurers have relied on each other to raise broadly defined capital. Between March 2000 and March 2001 the bankruptcies of Chiyoda, Kyoei, and Tokyo Life reduced the double - gearing, but it is still significant. At the end of March 2001, 7 life insurance companies collectively held 5.4 trillion yen of bank stocks and 5.1 trillion yen of bank subordinated debts. In exchange, banks hold 1 trillion yen of surplus notes and 1.2 trillion yen of subordinated debts of 7 life insurance companies.

The double-gearing generates two important problems: poor-quality capital in Japan's financial sector, which increases systemic risk, and a weaker governance structure of banks.

As regards systemic risk, suppose a major life insurer filed for bankruptcy. The banks that hold the company's subordinated loans and surplus notes lose money. The price of the stock of these banks falls to reflect the write-offs, which reduces the assets of insurance-companies holding bank stocks. It may even trigger a chain reaction of failures among Japanese financial institutions.

The corporate governance structure of Japan's major life insurance companies is weak. The "representative policyholder meeting" plays the role a shareholder meeting does for joint stock companies. Each representative policyholder has one vote. They are inevitably chosen by management. Sometimes, they become policyholders only after being asked to be a representative policyholder. In other cases, a manager of a company that borrows from the insurance company is asked. 
Stock prices of listed Japanese banks have been very weak since the end of 2001. I believe that this reflects a number of remaining problems in Japan's financial system. First, profit margins are too small to cover the increased default risk since the bubble burst more than 10 years ago. Many firms have not overcome their debt overhang and are surviving on the indulgence of their banks. Banks have not succeeded in increasing their lending margins because of strong competitive pressure from government-backed financial institutions. They also are facing strong political pressure to lend to small and medium firms regardless of merit. More broadly, revisions to the banking law require regulatory approval of new investors, and a condition of approval is that they "fully understand a bank's social responsibilities."

Second, there is massive double-gearing between life insurance companies and banks. Systemic risk remains very high. Financial sector problems can be stabilized by public money; either by injecting capital into the banks or by extending a full government guarantee of deposits, the government can stabilize the fragile financial system. However, a far larger problem will surface in that event: the critical situation of the national debt. Because of deflation and high real interest rates, the Japanese economy is shrinking. Nominal GDP declined 2\% in 2001 and such negative growth is likely to continue unless there are very strong policy actions.

Table 12 shows a simple projection of Japan's budgetary situations under minus $2 \%$ nominal growth and an unchanged primary deficit of $6 \%$ of GDP. I did not take account of the cost of stabilizing the financial system, but I did assume a massive cutting of government expenditures in line with declining tax revenue. The gross debt of the general government will exceed $200 \%$ of GDP by 2008.

If the government cannot stabilize the macro economy by stopping deflation, I expect Japanese yen government bonds (JGB) to be downgraded to speculative by 2007. (In July 2002 they had the lowest rating among major countries: AA- by Standard \& Poor's and A2 by Moody's.) If downgraded further, the government will have to shift to short-term notes to reduce interest costs. However, shortening maturity will increase vulnerability to a sharp rise in interest rates.

A junk bond status of JGB will generate enormous problems for the corporate sector. Sovereign credit usually sets a ceiling for private companies. Japanese banks will not be able to use JGBs as collateral in dealing with foreign banks. Moody's downgraded the major banks' financial strength to its lowest ratings on 2 July 2002. Japanese savers are shifting assets from yen deposits to foreign-currency deposits and 
gold. The relative weakness of the yen in the face of rapidly declining dollar interest rates in 2001 may have indicated a mild form of capital flight.

Massive capital flight will cure Japan's deflation by sharply devaluing the yen. However, other Asian countries will devalue against the dollar to remain competitive. That will export deflation to the rest of the world, including the United States. In that event, the United States may have to follow the Japanese example of a zero interest rate policy.

The end of deflation may trigger a budgetary crisis in Japan. Suppose Japan has $200 \%$ gross debt, mostly financed by short-term liabilities. Most of its financial assets are long-term and at fixed interest rates, so the government cannot count on a higher interest income in the short run under increasing interest rates. A 500 basis point rise in interest rates (which would make rates about the same as they were in 1991) will increase interest payments to $10 \%$ of GDP, $¥ 50$ trillion. This is about the same as total national government tax revenue excluding social security contributions.

Many Japanese policy makers and corporate leaders have spent more than 10 years assuming time will solve whatever the problems are with less pain and cost than will aggressive confrontation. Time not only has not solved the problems, it has made many of them worse. I would like to say the scenarios I have depicted are pessimistic assessments, but sadly they are all too possible. The pain and the cost will continue to grow, as the economy stagnates, unless a more immediate, comprehensive, and aggressive attack is made on the known problems. 


\section{References}

Bank of Japan, "Enhancing the Credit Risk Control with Self Classification of Bad Loans," Bank of Japan Bulletin, October 1997 (Japanese Edition).

Fukao, Mitsuhiro, "Japanese Financial Instability and Weaknesses in the Corporate Governance Structure," Seoul Journal of Economics, Vol. 1, No. 4, winter, 1998.

Fukao, Mitsuhiro, "Recapitalizing Japan Banks: The functions and problems of Financial Revitalization Act and Bank Recapitalization Act," Keio Business Review, 38, 2000.

Fukao, Mitsuhiro, Financial Integration, Corporate Governance, and the Performance of Multinational Companies, Brookings, 1995.

Fukao, Mitsuhiro and Japan Center for Economic Research, editors, Empirical Analysis of Financial Recession (Kinyu Fukyo no Jissho Bunseki), (in Japanese), Nikkei Sinbun Sha: Tokyo, 2000a.

Fukao, Mitsuhiro and Japan Center for Economic Research, editors. Examining Life Insurance Crisis (Kensho Seiho Kiki), (in Japanese), Nikkei Sinbun Sha: Tokyo, $2000 \mathrm{~b}$.

Higo, Masahiro, "The Current State of FILP System: the Effects of 2001 Reform on the Functions of the FILP," (in Japanese), Bank of Japan Economic Research Department Working Paper 01-1, March 2001.

Hoshi, Takeo, and Anil Kashyap. 1999. AThe Japanese Banking Crisis: Where did it Come From and How will it End?@In Ben S Bernanke and Julio J Rotemberg, editors, NBER Macroeconomics Annual 1999, 14, pp 129-201.

Inoue, Hideaki, "Accelerating Unwinding of Cross Shareholding," In Nissay Kisoken Report, October 1999.

Japanese Bankers Association. 2001. Analysis of Financial Statements of All Banks, 31 Mar 2001.

Japan Center for Economic Research (JECR), Structural Problems of Japanese Financial System, October 2000 (in Japanese).

Japan Center for Economic Research (JCER)Monetary Policy Under Deflation . March 2001 (in Japanese).

Japan Center for Economic Research (JCER), Weakening Japanese Financial System, October 2002 (in Japanese). 
Table 1

Problem Loans of Japanese Banks

\begin{tabular}{|c|c|c|c|c|c|c|c|c|c|c|c|}
\hline & $1993^{\mathrm{a}}$ & $1994^{\mathrm{a}}$ & $1995^{\mathrm{a}}$ & $1996^{\mathrm{b}}$ & $1997^{\mathrm{b}}$ & $1998^{\mathrm{c}}$ & $1999^{c}$ & $2000^{c}$ & $2001^{\mathrm{c}}$ & $2002^{\mathrm{c}}$ & \\
\hline & 945 & 1,146 & 1,402 & 7,087 & 3,447 & 8,402 & 8,118 & 2,531 & 2,732 & 5,196 & Specific reseves $^{2}$ \\
\hline & 424 & 2,090 & 2,808 & 5,980 & 4,316 & 3,993 & 4,709 & 3,865 & 3,072 & 3,974 & Writen off $^{3}$ \\
\hline A & 1,640 & 3,872 & 5,332 & 13,369 & 7,763 & 13,258 & 13,631 & 6,944 & 6,108 & 9,722 & Loss from bad loans ${ }^{4}$ \\
\hline $\mathrm{A}^{\prime}$ & 1,640 & 5,512 & 10,744 & 24,113 & 31,877 & 45,135 & 58,766 & 65,710 & 71,818 & 81,540 & Cumlative losses ${ }^{5}$ \\
\hline $\mathrm{B}$ & 12,775 & 13,576 & 12,546 & 28,504 & 21,789 & 29,858 & 29,627 & 30,366 & 32,515 & 42,028 & Bad loans outstanding $^{6}$ \\
\hline $\mathrm{D}$ & 3,698 & 4,547 & 5,536 & 13,294 & 12,334 & 17,815 & 14,797 & 12,230 & 11,555 & 13,353 & Loan loss reserves \\
\hline
\end{tabular}

Notes:

1 Data are for fiscal years ending in March of year shown.

2 Defined as the reserves held against individual bad loans.

3 Includes losses from sale of loans to the CCPC (Cooperative Credit Purchase Corp) and other counter parties.

4 Sum of the two previous rows.

5 Cumulative total (beginning with fiscal 1992) of losses from bad loans (in row A).

6 The series is not consistent because the definition and coverage of bad loans has been broadened twice. See notes a, b, and c. (For a detailed look at how the data have changed, see Hoshi and Kashyap 1999, section 4.)

a Only major banks disclosed loan loss figures. Bad-loan data are for defaulted loans and loans with arrears.

b Bad-loan data are for defaulted loans, loans with arrears for more than 6 months, and loans with concessional interest rates below the official discount rate of the Bank of Japan.

c Bad-loan data are for defaulted loans, loans with arrears for more than 90 days, and loans with concessional terms. (Similar to US rules.)

Source: Data are available from the Financial Services Agency web site [www.fsa.go.jp]. 
Table 2

Analysis of Japanese Bank Loans, 1997-2002

\begin{tabular}{|c|c|c|c|c|c|c|c|}
\hline & $1997^{\mathrm{a}}$ & 1998 & 1999 & 2000 & 2001 & 2002 & \\
\hline & 550,000 & 544,814 & 487,500 & 472,388 & 470,669 & 490,537 & Normal loans \\
\hline & 76,700 & 71,700 & 64,258 & 63,386 & 65,671 & 71,087 & $\begin{array}{l}\text { Classified loans total } \\
\text { composed of: }\end{array}$ \\
\hline & 65,300 & 65,500 & 61,024 & 60,539 & 63,118 & 67,787 & Substandard \\
\hline & 8,700 & 6,100 & 3,160 & 2,835 & 2,553 & 3,300 & Doubtful \\
\hline & 2,700 & 100 & 74 & 12 & 0 & 0 & Estimated loss \\
\hline $\mathrm{C}$ & 27,350 & 22,918 & 19,366 & 18,828 & 19,117 & 20,273 & Required reserves $^{2}$ \\
\hline $\mathrm{D}$ & 12,334 & 17,815 & 14,797 & 12,230 & 11,555 & 13,353 & Actual reserves \\
\hline & 15,016 & 5,103 & 4,569 & 6,592 & 7,562 & 6,920 & Under reserved (C-D) \\
\hline
\end{tabular}

Notes:

1 Data are for fiscal years ending in March of year shown.

2 Author's estimates based on $1 \%$ of normal loans plus $20 \%$ of substandard loans plus $70 \%$ of doubtful loans plus $100 \%$ of estimated loss loans.

a Classifed loan data are based on MOF announcements.

Source: Data are available from the Financial Services Agency web site [www.fsa.go.jp]. 
Table 3

\section{Cumulative Loss Rate ${ }^{1}$}

\begin{tabular}{|c|c|c|}
\hline \multicolumn{2}{|c|}{$\begin{array}{c}\text { Classification of } \\
\text { Loan in March } 1994\end{array}$} & \multirow{2}{*}{$\begin{array}{l}\text { Years later and } \\
\text { Time (March } \\
\text { of year shown) }\end{array}$} \\
\hline Sub-standard & Doubt-ful & \\
\hline 1.7 & 27.4 & 1 year, 1995 \\
\hline 9.8 & 52.1 & 2 years, 1996 \\
\hline 16.7 & 75.3 & 3 years, 1997 \\
\hline
\end{tabular}

Notes:

1 Percentage of loans in the classification in March 1994 that had been written off at the end of each time period. Data are for an 18-bank sample.

Source: Bank of Japan 1997.

Table 4

Distribution of Adjusted Capital-Asset Ratios of Major Banks

\begin{tabular}{|c|c|c|c|c|c|c|}
\hline $\begin{array}{l}1998 \\
\text { Mar }\end{array}$ & $\begin{array}{l}1999 \\
\text { Mar }\end{array}$ & $\begin{array}{l}2000 \\
\text { Mar }\end{array}$ & $\begin{array}{l}2000 \\
\text { Sep }\end{array}$ & $\begin{array}{l}2001 \\
\text { Mar }\end{array}$ & $\begin{array}{r}2001 \\
\text { Sep }\end{array}$ & $\begin{array}{l}\text { level of adjusted } \\
\text { capital as } \% \text { assets }\end{array}$ \\
\hline 2 & 0 & 0 & 0 & 1 & 1 & less than $-2 \%$ \\
\hline 6 & 2 & 0 & 0 & 0 & 3 & -2 to less than $0 \%$ \\
\hline 8 & 2 & 0 & 0 & 1 & 4 & subtotal, insolvent \\
\hline 8 & 10 & 4 & 5 & 8 & 11 & 0 to less than $2 \%$ \\
\hline 3 & 5 & 9 & 10 & 6 & 0 & $2 \%$ to less than $4 \%$ \\
\hline 0 & 0 & 4 & 0 & 0 & 0 & $4 \%$ to less than $6 \%$ \\
\hline 19 & 17 & 17 & 15 & 15 & 15 & Total number of banks \\
\hline 0.93 & 2.07 & 3.48 & 2.36 & 1.83 & 0.86 & Weighted average $\%$ \\
\hline
\end{tabular}

Last day of months shown. Fiscal 1997 ended 31 March 1998, etc.

1 Adjusted capital is defined as core capital plus unrealized capital gains and losses plus loan loss reserves minus estimated loan losses minus deferred tax asset. As in Table 2, estimated loan losses is defined as $1 \%$ of normal loans plus $20 \%$ of substandard loans plus $70 \%$ of doubtful loans plus $100 \%$ of estimated loss loans. Individual banks do not disclose data on classified loans individually, so I relied on disclosed bad loan data.

Source: Updated by the author from JCER 2001. 
Table 5

Stock portfolios and capital in the banking sector

\begin{tabular}{|c|c|c|c|c|c|c|c|c|}
\hline & $\begin{array}{c}\text { Market } \\
\text { value of } \\
\text { shares } \\
\text { A }\end{array}$ & $\begin{array}{c}\text { Book value } \\
\text { of shares } \\
\text { B }\end{array}$ & $\begin{array}{c}\text { Capital account } \\
\text { (Core capital) } \\
\text { C }\end{array}$ & $\begin{array}{c}\text { Deferred } \\
\text { Tax asset } \\
\text { D }\end{array}$ & $\begin{array}{c}\text { Estimated } \\
\text { Under-reserving } \\
\mathrm{E}\end{array}$ & $\begin{array}{l}\text { Equity capital } \\
\text { held by the } \\
\text { government } \\
\text { F }\end{array}$ & $\begin{array}{l}\text { Net capital Account } \\
\text { C+(A-B) } \times \\
0.6-D-E-F\end{array}$ & $\begin{array}{c}\text { Nikkei225 } \\
\text { Index }\end{array}$ \\
\hline Mar-86 & 46.9 & 11.9 & 12.3 & 0.0 & $\mathrm{NA}$ & 0.0 & 33.3 & 15860 \\
\hline Mar-87 & 63.7 & 13.4 & 13.8 & 0.0 & NA & 0.0 & 44.0 & 21567 \\
\hline Mar-88 & 77.6 & 17.6 & 17.2 & 0.0 & NA & 0.0 & 53.2 & 26260 \\
\hline Mar-89 & 97.1 & 23.2 & 22.5 & 0.0 & NA & 0.0 & 66.8 & 32839 \\
\hline Mar-90 & 88.6 & 29.7 & 28.6 & 0.0 & NA & 0.0 & 63.9 & 29980 \\
\hline Mar-91 & 77.7 & 33.1 & 30.2 & 0.0 & NA & 0.0 & 57.0 & 26292 \\
\hline Mar-92 & 56.4 & 34.5 & 31.3 & 0.0 & NA & 0.0 & 44.4 & 19346 \\
\hline Mar-93 & 56.4 & 34.5 & 31.8 & 0.0 & NA & 0.0 & 44.9 & 18591 \\
\hline Mar-94 & 61.9 & 36.5 & 32.3 & 0.0 & NA & 0.0 & 47.5 & 19112 \\
\hline Mar-95 & 52.0 & 39.8 & 32.3 & 0.0 & NA & 0.0 & 39.6 & 15140 \\
\hline Mar-96 & 64.3 & 43.0 & 27.9 & 0.0 & NA & 0.0 & 40.7 & 21407 \\
\hline Mar-97 & 54.1 & 42.9 & 28.5 & 0.0 & 15.0 & 0.0 & 20.2 & 18003 \\
\hline Mar-98 & 50.8 & 45.7 & 24.5 & 0.0 & 5.1 & 0.3 & 22.2 & 16527 \\
\hline Mar-99 & 47.1 & 42.7 & 33.7 & 8.4 & 4.6 & 6.3 & 17.1 & 15837 \\
\hline Mar-00 & 54.5 & 44.4 & 35.2 & 8.1 & 6.6 & 6.9 & 19.7 & 20337 \\
\hline Mar-01 & 44.5 & 44.3 & 36.7 & 7.3 & 7.6 & 7.1 & 14.8 & 13000 \\
\hline Mar-02 & 34.4 & 34.4 & 29.3 & 10.7 & 6.9 & 7.2 & 4.5 & 11025 \\
\hline
\end{tabular}

Source of data: $\quad$ Federation of Bankers Associations of Japan, "Analysis of Bank Financial Statements," various issues; securities reports for individual banks. Both market and book values represent listed shares only. The Table pertains to banking accounts of all banks in Japan.

Note: The market value of stock portfolios was not published prior to March 1990, so we have estimated backwards using the Niikkei 225 share price index from the end of March 1991. However, the tables for 1985-1986 should be discounted, because bank stock portfolios have been gradually increasing, so that values estimated from the end of fiscal 1990 will have an upwards bias the father back one goes. $40 \%$ corporate tax rate is assumed. See Table 2 for the estimation of under reserving. 
Table 6

Profitability of Japanese Banking Sector

(trillion yen)

\begin{tabular}{|c|c|c|c|c|c|c|c|c|c|c|c|c|c|c|}
\hline & 1989 & 1990 & 1991 & 1992 & 1993 & 1994 & 1995 & 1996 & 1997 & 1998 & 1999 & 2000 & 2001 & \\
\hline $\mathrm{A}$ & 7.5 & 7.1 & 8.9 & 9.8 & 9.2 & 9.7 & 10.8 & 10.7 & 10.0 & 9.6 & 9.7 & 9.4 & 9.8 & Lending margin \\
\hline B & 2.5 & 2.6 & 2.2 & 2.5 & 2.8 & 2.1 & 3.3 & 3.7 & 3.6 & 3.1 & 2.5 & 3.0 & 3.1 & Other revenue \\
\hline \multirow[t]{2}{*}{$\mathrm{C}$} & 6.6 & 7.1 & 7.5 & 7.7 & 7.7 & 7.8 & 7.8 & 8.0 & 8.0 & 7.5 & 7.3 & 7.1 & 7.0 & Operating costs \\
\hline & 3.5 & 3.7 & 3.9 & 4.0 & 4.0 & 4.0 & 4.0 & 4.0 & 4.0 & 3.6 & 3.5 & 3.4 & 3.2 & Salaries and wages (part of C) \\
\hline $\mathrm{D}$ & 3.3 & 2.6 & 3.5 & 4.5 & 4.3 & 4.0 & 6.3 & 6.4 & 5.6 & 5.2 & 4.9 & 5.3 & 5.9 & Gross profit $=\mathrm{A}+\mathrm{B}-\mathrm{C}$ \\
\hline $\mathrm{E}$ & 1.4 & 0.8 & 1.0 & 2.0 & 4.6 & 6.2 & 13.3 & 7.3 & 13.5 & 13.5 & 6.3 & 6.6 & 9.4 & Loan losses \\
\hline $\mathrm{F}$ & 1.9 & 1.8 & 2.5 & 2.5 & -0.4 & -2.2 & -7.0 & -1.0 & -7.9 & -8.3 & -1.4 & -1.3 & -3.5 & Net operating profit $=\mathrm{D}-\mathrm{E}$ \\
\hline \multirow[t]{4}{*}{$\mathrm{G}$} & 2.8 & 2.0 & 0.7 & 0.0 & 2.0 & 3.2 & 4.4 & 1.2 & 3.6 & 1.4 & 3.8 & 1.4 & -2.4 & Realized capital gains $^{2}$ \\
\hline & 4.7 & 3.8 & 3.3 & 2.5 & 1.7 & 1.0 & -2.6 & 0.2 & -4.2 & -6.9 & 2.3 & 0.1 & -5.9 & Net profit $=\mathrm{F}+\mathrm{G}$ \\
\hline & 943.6 & 927.6 & 914.4 & 859.5 & 849.8 & 845.0 & 848.2 & 856.0 & 848.0 & 759.7 & 737.2 & 804.3 & 772.0 & Assets \\
\hline & .. & 424.3 & 445.8 & 460.3 & 472.3 & 477.8 & 482.7 & 482.3 & 477.9 & 472.6 & 463.4 & 456.9 & 465.0 & Outstanding loans ${ }^{3}$ \\
\hline
\end{tabular}

Note: Financial Statement of All Commercial Banks.

Data are for fiscal years, which end in March of following calendar year.

1 Includes all other profit, such as trading for own account and fees, but excludes capital gains realized from stock and real estate sales (which are in row $\mathrm{G}$ ).

2 From sale of stocks and real estate.

3 Domestic banks only.

Source: JCER 2001, updated by the author. 
Table 7

Size of Government and Private Financial Institutions, 2000

\begin{tabular}{|c|c|c|c|}
\hline \multirow{3}{*}{$\begin{array}{c}\begin{array}{c}\text { Trillion } \\
\text { yen }\end{array} \\
\text { Joans }\end{array}$} & Assets & \multirow{2}{*}{$\begin{array}{c}\text { Market } \\
\text { share } \\
(\%)\end{array}$} & \\
\hline & $\begin{array}{c}\text { as } \% \\
\text { of GDP }\end{array}$ & & \\
\hline & \multicolumn{3}{|c|}{ Loans } \\
\hline 163 & 32 & 26 & Government \\
\hline 464 & 90 & 74 & Private banks \\
\hline 627 & 122 & - & Total \\
\hline \multicolumn{4}{|l|}{ Deposits } \\
\hline 255 & 50 & 34 & Postal Savings System \\
\hline 486 & 95 & 66 & Private banks \\
\hline 741 & 144 & - & Total \\
\hline \multicolumn{4}{|l|}{ Life Insurance } \\
\hline 119 & 23 & 40 & Postal Life \\
\hline 180 & 35 & 60 & Private insurers \\
\hline 299 & 58 & - & Total \\
\hline
\end{tabular}

Computed by the author from calendar year-end data in BOJ Financial and Economics Statistics Monthly, March 2001.

Table 8

Lending Rates of Government Lending Agencies, 9 Feb 2001

\begin{tabular}{ccl}
\hline \hline $\begin{array}{c}\text { Basic loan rate } \\
(\%)\end{array}$ & $\begin{array}{c}\text { Average term } \\
\text { (yrs) }\end{array}$ & \\
\hline 2.05 & 16.7 & Japan Development Bank \\
2.05 & 7.3 & People's Finance Corp \\
2.05 & 8.9 & Japan Finance Corp for Small Business \\
1.9 &.. & Japan Finance Corp for Municipal Enterprises \\
2.7 & 25.4 & Housing Loan Corp \\
& & \\
2.12 & $<1$ & Average of all private banks \\
4.65 & 20 & Fixed rate housing loan from Fuji Bank \\
\hline
\end{tabular}

All rates are fixed except the average of all private banks.

Source: JCER 2001. 
Table 9

Failed Life Insurance Companies

Condition at the time of Bankruptcy

\begin{tabular}{|c|c|c|c|c|c|c|c|}
\hline Name & Nissan & Toho & Daihyaku & Taisho & Chiyoda & Kyoei & Tokyo \\
\hline Legal Structure & Mutual & Mutual & Mutual & LLC & Mutual & LLC & Mutual \\
\hline Date of Failure & Apr-97 & Jun-98 & May-00 & May-00 & Oct- 00 & Oct- 00 & Mar-01 \\
\hline Asset (trillion yen) & 1.82 & 2.19 & 1.30 & 0.15 & 2.23 & 3.73 & 0.69 \\
\hline Equity (trillion yen) & -0.32 & -0.65 & -0.32 & -0.03 & -0.60 & -0.69 & -0.07 \\
\hline Disclosed solvency margin (SM) & N.A. & 154 & 305 & 68 & 263 & 211 & 447 \\
\hline Date associate with the SM & N.A. & Mar-98 & Mar-99 & Mar-00 & Mar-00 & Mar-00 & Mar-00 \\
\hline Reduction of reserves by bankruptcy & $0 \%$ & $10 \%$ & $10 \%$ & $10 \%$ & $10 \%$ & $8 \%$ & $0 \%$ \\
\hline Average guaranteed Return before failure & $3.75-5.5 \%$ & $4.79 \%$ & $4.46 \%$ & $4.05 \%$ & $3.70 \%$ & $4.00 \%$ & $4.20 \%$ \\
\hline Guaranteed return after failure & $2.75 \%$ & $1.50 \%$ & $1.00 \%$ & $1.00 \%$ & $1.50 \%$ & $1.75 \%$ & $2.60 \%$ \\
\hline Early withdrawal charges (EWC) & $15 \% ? 3 \%$ & $15 \% ? 2 \%$ & $20 \% ? 2 \%$ & $15 \% ? 3 \%$ & $20 \% ? 2 \%$ & $15 \% ? 2 \%$ & $20 \% ? 2 \%$ \\
\hline Period of EWC & 7 years & 8 years & 10 years & 10 years & 10 years & 8 years & 10 years \\
\hline
\end{tabular}

Source: Japan Center for Economic Research, Deflation and the Financial System Reform, October 2001.

Note: LLC stands for limited liability company. The sliding scale for the early withdrawal charges is described in the text. 
Table 10

Solvency Margins of Major Life Insurers

\begin{tabular}{rcrccl}
\hline \hline \multicolumn{1}{c}{1998} & 1999 & 2000 & 2001 & 2002 & \multicolumn{1}{c}{ Company $^{1}$} \\
\hline 154.3 & - & - & - & - & Toho \\
294.6 & 304.6 & - & - & - & Daihyaku \\
314.2 & 396.1 & 263.1 & - & - & Chiyoda \\
300.7 & 343.2 & 210.6 & - & - & Kyoei \\
431.6 & 478.7 & 446.7 & - & - & Tokyo \\
& & & & & \\
654.8 & 688.8 & 732.7 & 543.4 & 417.6 & Asahi \\
1016.8 & 998.0 & 1004.2 & 757.6 & 772.0 & Daido \\
632.1 & 662.1 & 858.6 & 682.3 & 593.0 & Daiichi \\
722.4 & 820.6 & 906.5 & 779.3 & 708.2 & Fukoku \\
719.9 & 706.1 & 731.0 & 667.2 & 609.4 & Meiji \\
491.6 & 519.6 & 676.7 & 492.7 & 510.7 & Mitsui \\
939.9 & 849.9 & 1095.8 & 778.1 & 714.4 & Nippon \\
526.2 & 589.5 & 675.7 & 551.3 & 534.5 & Sumitomo \\
873.0 & 869.1 & 1050.3 & 806.8 & 768.2 & Taiyo \\
648.1 & 727.2 & 808.5 & 602.6 & 612.8 & Yasuda \\
\hline
\end{tabular}

The first five are listed in the order in which they went bankrupt. Others are listed alphabetically.

1 "Life" is the second word in the names of all these companies. 
Table 11

Comparison of US and Japanese Capital Requirements for Life Insurance Companies

\begin{tabular}{|c|c|c|}
\hline & US RBC regulation & $\begin{array}{c}\text { Japanese Solvency } \\
\text { Margin regulation }\end{array}$ \\
\hline \multicolumn{3}{|l|}{$\begin{array}{l}\text { Assets of no liquidation value } \\
\text { in the net asset calculation }\end{array}$} \\
\hline Deferred tax asset & Not allowed & Allowed \\
\hline Movable property & Not allowed & Allowed \\
\hline Future profit & Not allowed & $\begin{array}{l}\text { One year profit until March } 2000 \text {; } \\
\text { half year profit is allowed since then }\end{array}$ \\
\hline \multicolumn{3}{|l|}{ Unrealized losses } \\
\hline in domestic bonds & Deducted from asset & $\begin{array}{l}\text { Not deducted from assets } \\
\text { until March } 2001\end{array}$ \\
\hline in foreign securities & Deducted from asset & $\begin{array}{l}\text { Not deducted from assets } \\
\text { until March } 2001\end{array}$ \\
\hline \multicolumn{3}{|l|}{ Weights for market risk } \\
\hline Stocks & $22.5-45 \%$ & $10 \%$ \\
\hline Foreign bonds & $10 \%$ & $5 \%$ \\
\hline Real estates & $10 \%$ & $5 \%$ \\
\hline \multicolumn{3}{|l|}{$\begin{array}{l}\text { Trigger levels for the initiation } \\
\text { of prompt corrective actions }\end{array}$} \\
\hline No action & $250 \%$ & $200 \%$ \\
\hline Submit plans for improvements & $150-250 \%$ & $100-200 \%$ \\
\hline Stronger intervention & $70-150 \%$ & $0-100 \%$ \\
\hline Authority takes over the control & Less than $70 \%$ & Less than $0 \%$ \\
\hline
\end{tabular}


Table 12

Projection for General Government Budget Deficits

\begin{tabular}{|c|c|c|c|c|c|c|}
\hline Year & $\begin{array}{c}\text { Nominal } \\
\text { GDP Growth } \\
\text { Rate }\end{array}$ & $\begin{array}{l}\text { Primary Surplus } \\
\text { to GDP Ratio }\end{array}$ & $\begin{array}{c}\text { General Government } \\
\text { Gross Debt } \\
\text { to GDP Ratio }\end{array}$ & $\begin{array}{c}\text { General Government } \\
\text { Net Debt } \\
\text { to GDP Ratio }\end{array}$ & $\begin{array}{l}\text { Effective Interest } \\
\text { Rate on Net Debt }\end{array}$ & $\begin{array}{l}\text { Net Interest Cost } \\
\text { to GDP Ratio }\end{array}$ \\
\hline 1999 & -0.6 & -5.7 & 120.4 & 36.0 & 3.5 & 1.3 \\
\hline 2000 & -0.1 & -6.8 & 130.7 & 43.5 & 3.3 & 1.4 \\
\hline 2001 & -1.9 & -5.9 & 142.0 & 51.0 & 2.9 & 1.5 \\
\hline 2002 & -2.0 & -6.0 & 150.6 & 59.6 & 2.5 & 1.5 \\
\hline 2003 & -2.0 & -6.0 & 159.3 & 68.3 & 2.1 & 1.4 \\
\hline 2004 & -2.0 & -6.0 & 168.1 & 77.1 & 2.1 & 1.6 \\
\hline 2005 & -2.0 & -6.0 & 177.4 & 86.4 & 2.3 & 2.0 \\
\hline 2006 & -2.0 & -6.0 & 187.2 & 96.2 & 2.7 & 2.6 \\
\hline 2007 & -2.0 & -6.0 & 197.8 & 106.8 & 3.0 & 3.2 \\
\hline 2008 & -2.0 & -6.0 & 209.2 & 118.2 & 4.0 & 4.7 \\
\hline 2009 & -2.0 & -6.0 & 222.5 & 131.5 & 4.0 & 5.3 \\
\hline
\end{tabular}

Note: Figures until 2001 are based on IMF, World Economic Outlook and OECD, Economic Outlook.

General government gross asset is assumed to be constant after 2001.

Sharp downgradings of JGB are assumed after 2005. 
Figure 1

Comparison of the Bad Loan Situation in Japan and the United States

Bad loan/total loan ratio

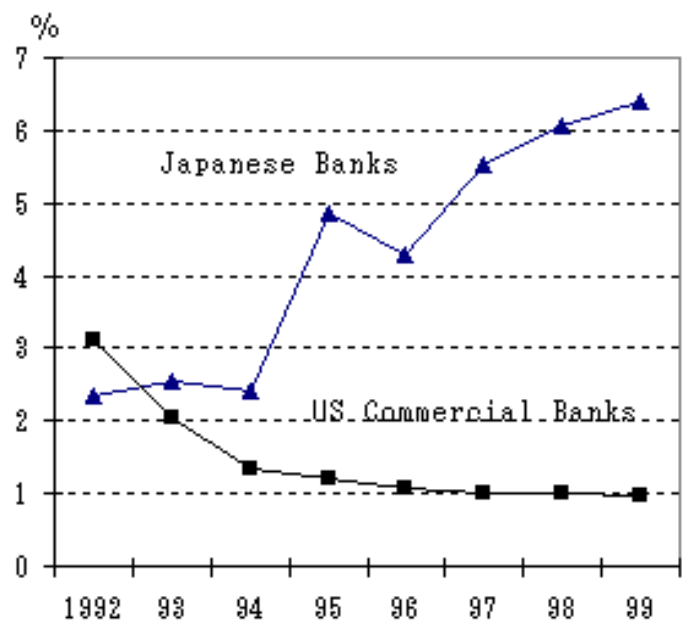

1) Japan: fiscal year, US:

calendar year

2) Figures after FY 1997 do not include data of Hokkaido Takushoku Bank, Tokuyo City Bank, Kyoto Kyoei Bank, Naniwa Bank, Fukutoku Bank, and Midori Bank.

3) Japanese bad loan ratio $=$ Risk control loans/total loans US bad loan ratio $=$ (loans with arrears for more than 90 days + loans that do not count accrued interest rates as asset + restructured loans)/total loans.

Source: Japan Center for Economic Research, Monetary Policy Under Deflation, March 2001 (in Japanese). 
Figure 2

Comparison of the Loan Loss Provisioning in Japan and the United States

Loan loss reserve/bad loan ratio

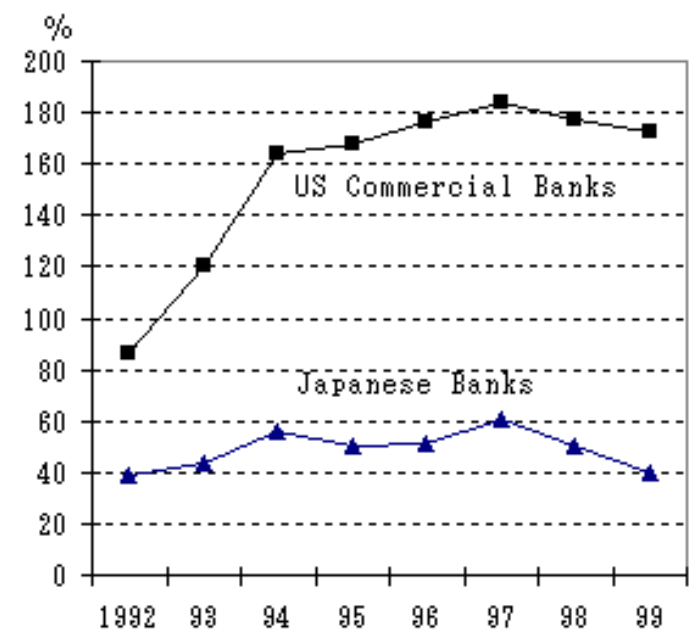

1) Japan: fiscal year, US: calendar year

2) Figures after FY 1997 do not include data of Hokkaido Takushoku Bank, Tokuyo City Bank, Kyoto Kyoei Bank, Naniwa Bank, Fukutoku Bank, and Midori Bank.

3) Japanese bad loan ratio $=$ Risk control loans/total loans US bad loan ratio $=$ (loans with arrears for more than 90 days + loans that do not count accrued interest rates as asset + restructured loans)/total loans.

Source: Japan Center for Economic Research, Monetary Policy Under Deflation, March 2001 (in Japanese). 
Figure 3

Japanese Banks Bad Loan-Total Loan Ratios

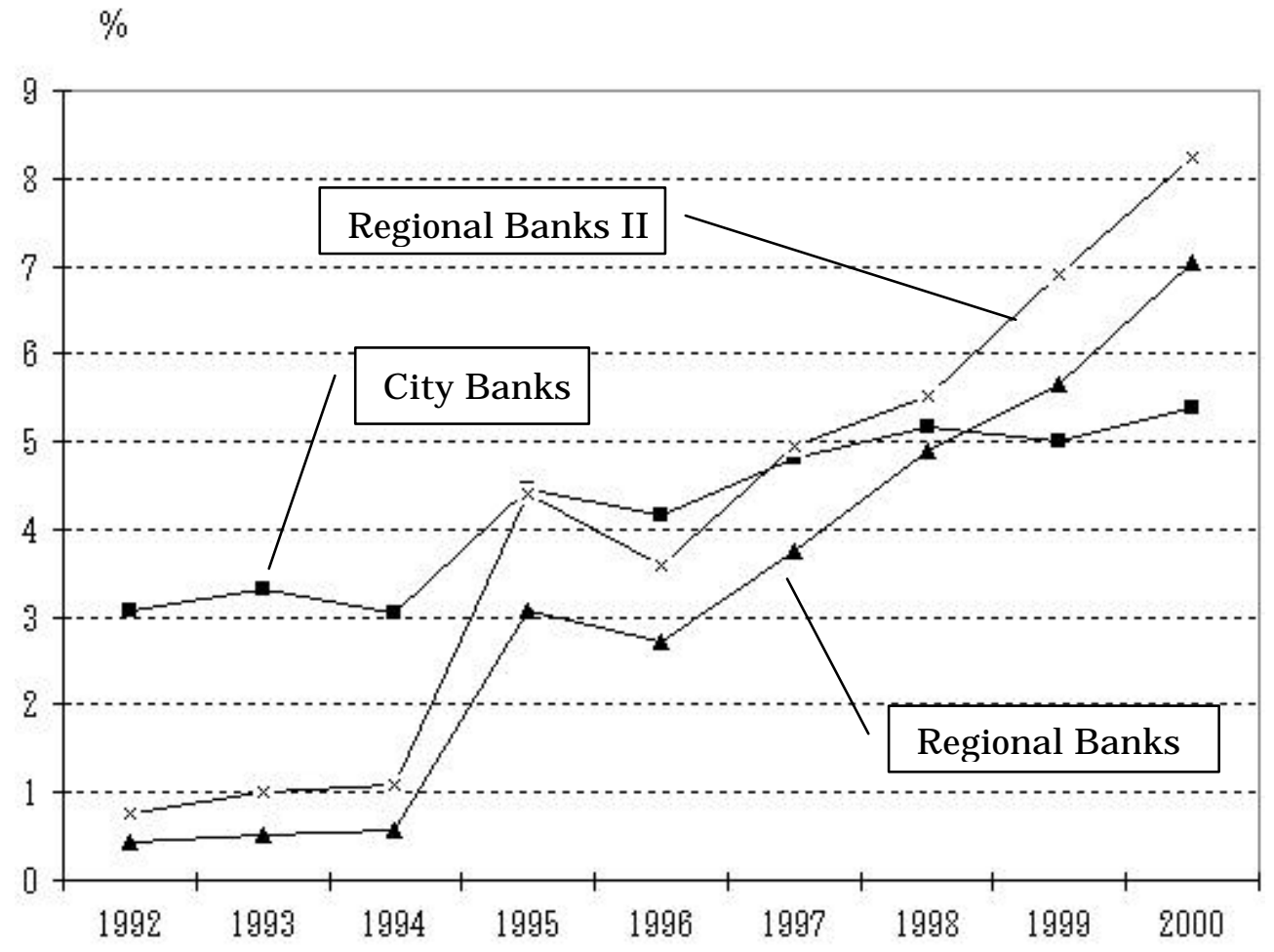

Source: Japan Center for Economic Research, Monetary Policy Under Deflation, March 2001 (in Japanese). 
Figure 4

Decomposition of Lending Margin

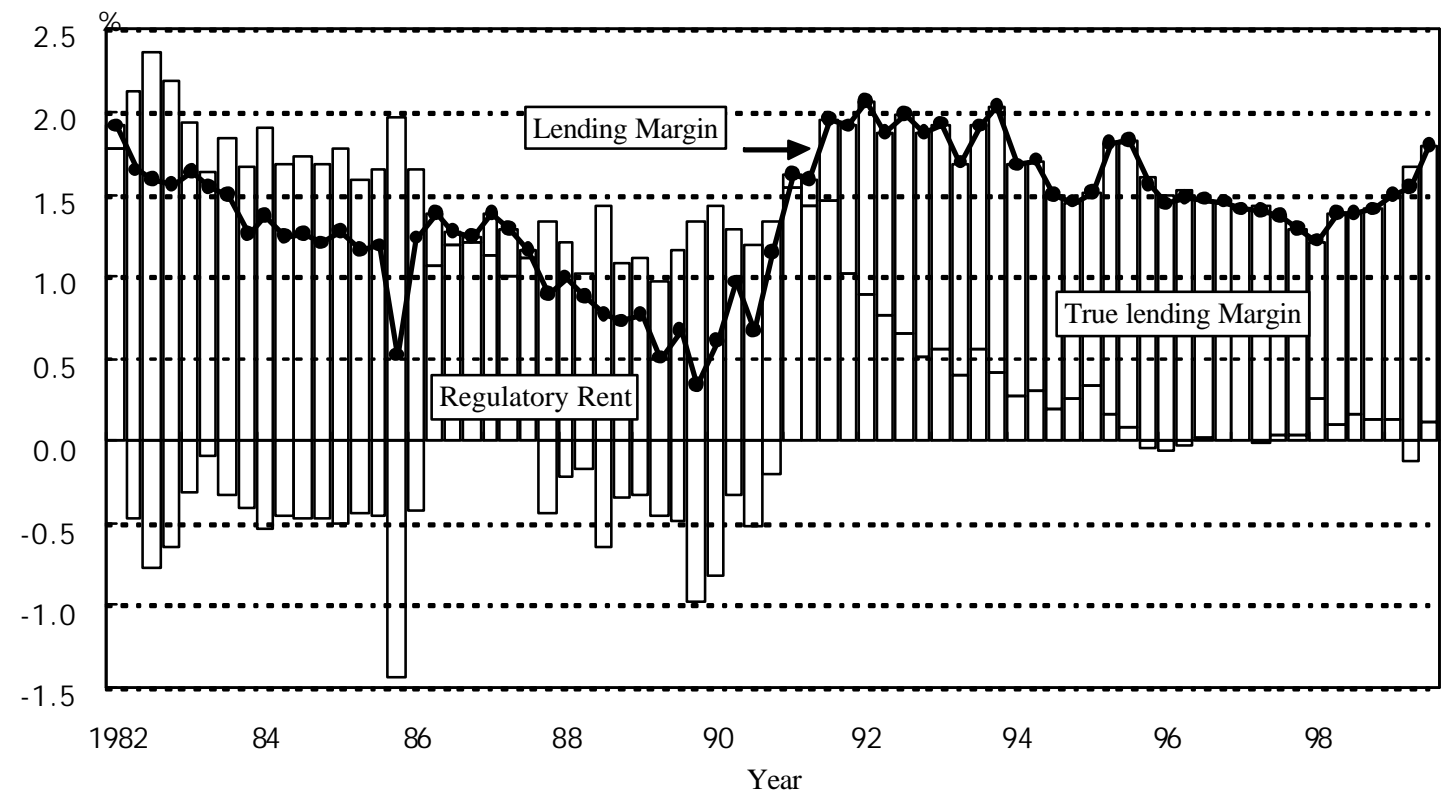

Source: Ikuko Fueda, "Financial liberalization, asset bubble, and bank behavior," in M. Fukao and JCER ed, Empirical Analysis of Financial Recession," Japan Economic Journal, 2000 . 
Figure 5

\section{Nominal and Real Interest Rates}

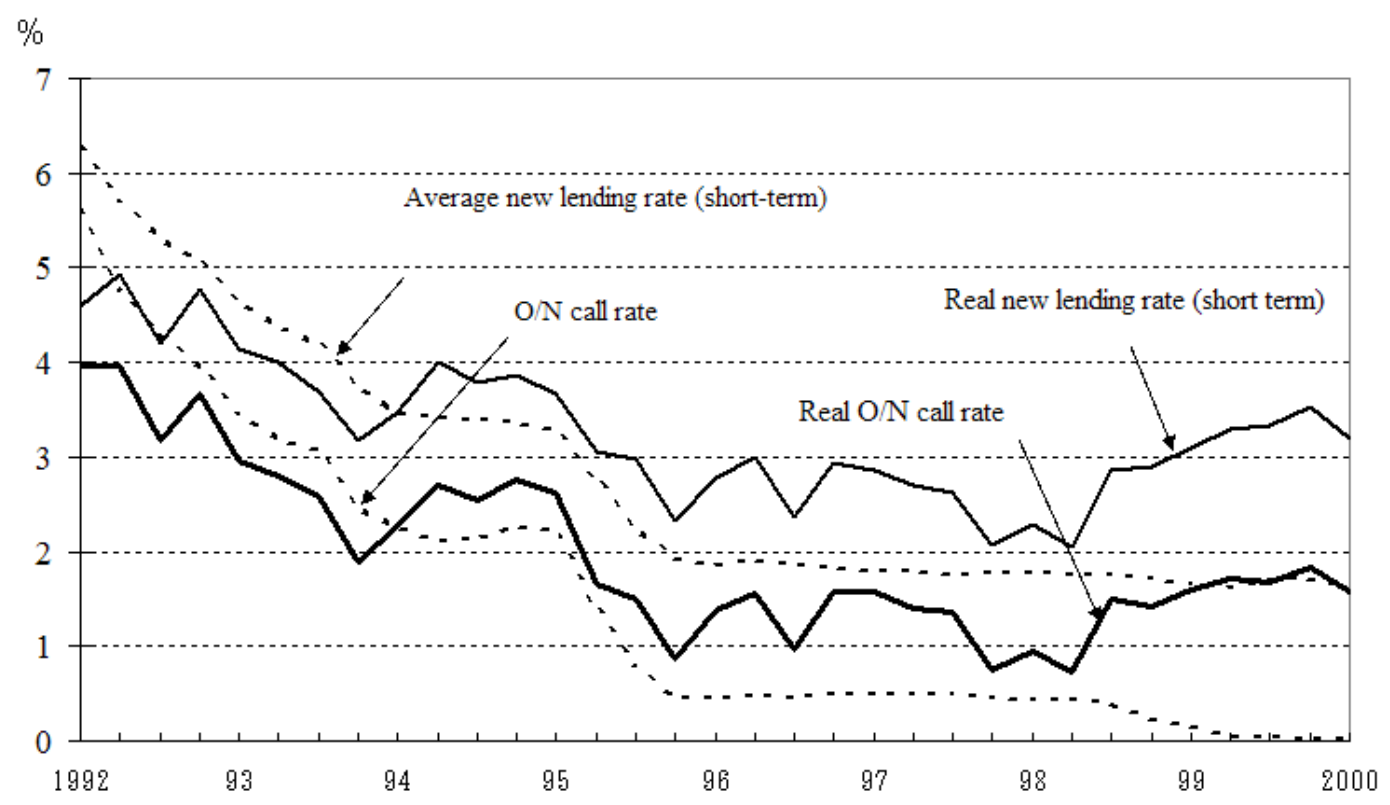

Note: Real interest rates are calculated by subtracting GDP deflator inflation rates from nominal interest rates.

The GDP deflator inflation rate is adjusted for changes in consumption tax rates in 1989 and 1997.

Source: Japan Center for Economic Research, Monetary Policy Under Deflation, March 2001 (in Japanese). 
Figure 6

Adjusted Solvency Margin Ratios March 2000

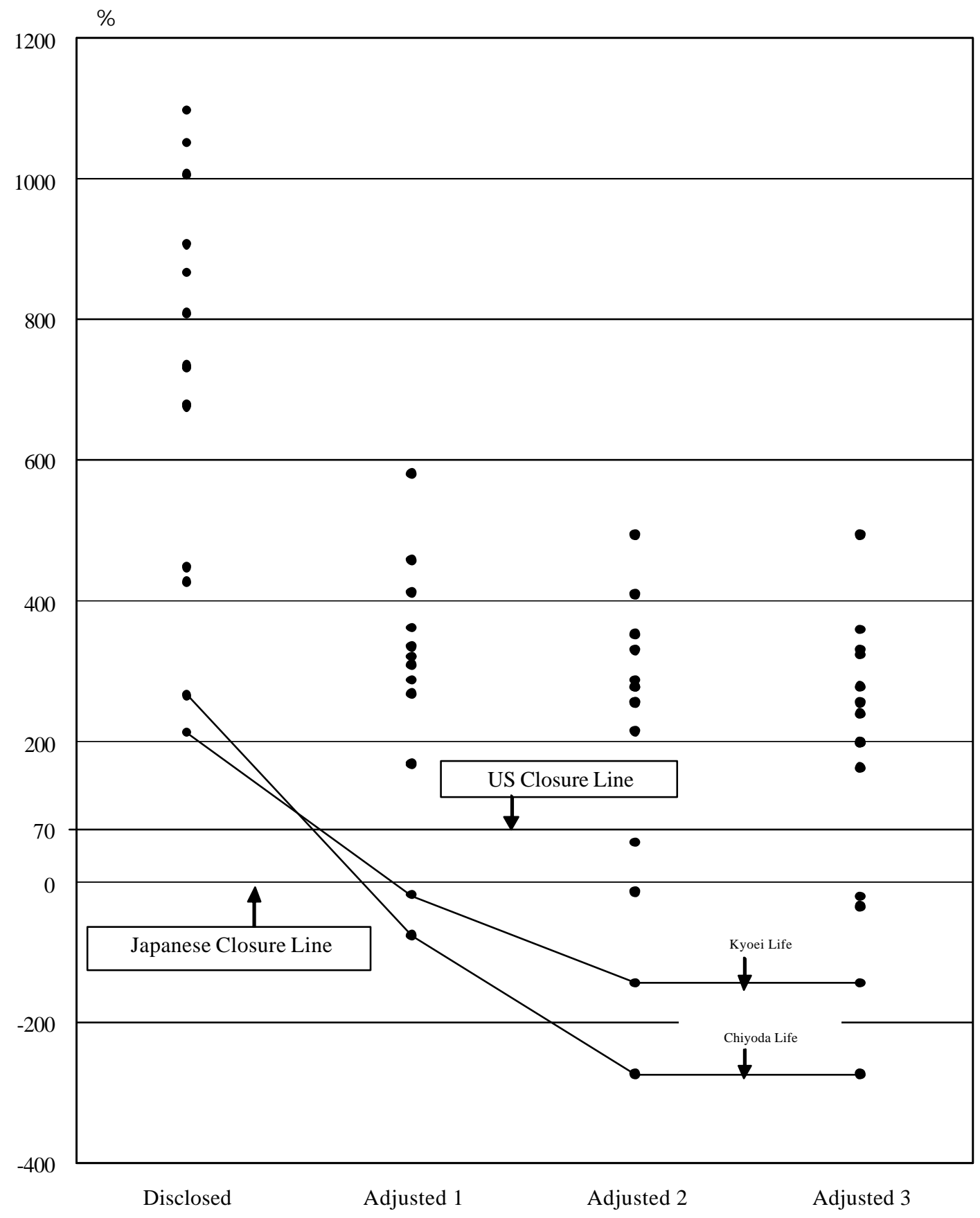

Source: Japan Center for Economic Research, Structural Problems of Japanese Financial System, October 2000 (in Japanese). 
Figure 7 Japanese Life Insurers' Adjusted Solvency Margin Ratios, March 2002

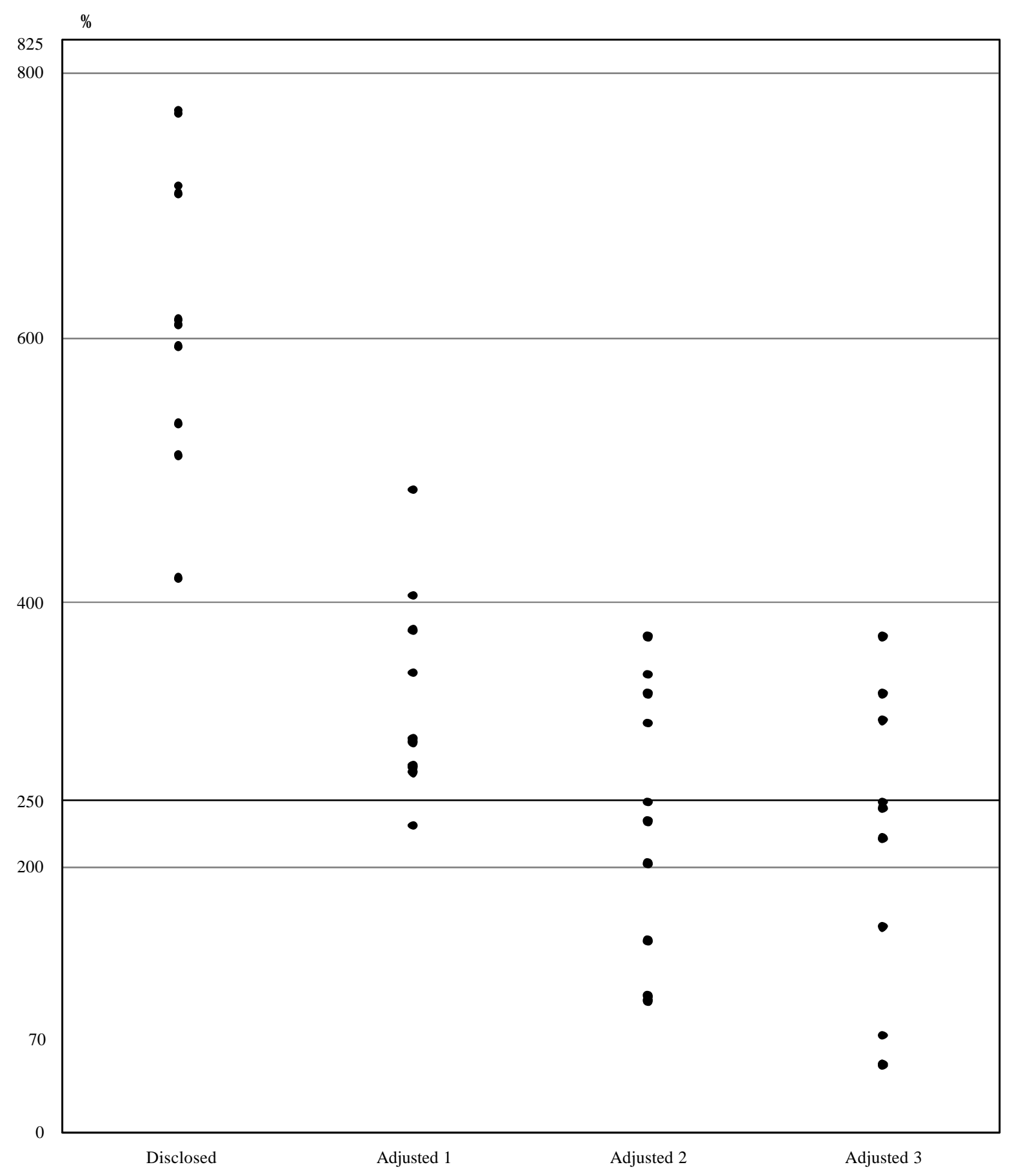

Source: Japan Center for Economic Research, Weakening Japanese Financial System, October 2002 (in Japanese). 